\title{
Interaction between Chinese Family Business and Cultural Differences in Malaysia
}

\author{
Iskandar Hasan Tan Abdullah ${ }^{1}$, Muhammad Syahmizan Azmi ${ }^{1}$, Sakinah Mat Zin ${ }^{2}$, Lim Soo Chee ${ }^{3}$ \& Nur Azuki \\ Yusoff ${ }^{4}$ \\ ${ }^{1}$ Faculty of Administrative Science and Public Policy, University Technology MARA (UiTM) Kelantan, \\ Malaysia \\ ${ }^{2}$ Faculty of Business Management, University Technology MARA (UiTM) Kelantan, Terengganu, Malaysia \\ ${ }^{3}$ Faculty of Business Management, Open University of Malaysia, Malaysia \\ ${ }^{4}$ Center for Language Studies and Generic Development, University of Malaysia Kelantan, Bachok, Kelantan, \\ Malaysia \\ Correspondence: Iskandar Hasan Tan Abdullah, Faculty of Administrative Science and Public Policy, University \\ Technology MARA (UiTM) of Terengganu, Malaysia. E-mail: iskandartan@yahoo.com
}

Received: February 3, 2014 Accepted: March 6, 2014 Online Published: April 29, 2014

doi:10.5539/ass.v10n10p118 URL: http://dx.doi.org/10.5539/ass.v10n10p118

\begin{abstract}
Family business inheritance among the Chinese community is a tradition that is known by the business community worldwide. Thus, a family business among the Chinese community in Malaysia is common. In fact, the inheritance of this business provides a unique and exciting dimension to be investigated. The paper explores the empirical evaluation on the influence of family business inheritance among the Chinese; who managed to overcome obstacles and conflicts through discussions and negotiations. Using a correlation test to examine the effect of inheritance in a family business among the Chinese, the study stress on the variables such as power distance, uncertainty avoidance, and masculinity vs. femininity, individualism vs. collectivism, time orientation and impact on value dimension. In addition, factor analysis and regression testing are also used to determine the main determinant factor in the family business inheritance among the Chinese community. Primary data were collected from August to October 2011 using questionnaires. Meanwhile, secondary data were gathered through library research and interviews with Chinese traders on the East Coast of Malaysia. From the qualitative study, it is found that the main reasons for refusal to inherit the family business among the younger Chinese generation is due to jobs that offer the lucrative wages as compared to profits earned in the family business. Job status, educational level and age are also the factors that influence the younger Chinese generation not to inherit the family business.
\end{abstract}

Keywords: Chinese family business, succession planning and business inheritance

\section{Introduction}

Traditional businesses fall into the category of Small Medium Enterprises (Dunne \& Lusch, 2011). One of those is family held businesses which is among the most important contributors to wealth and employment creation in virtually every country in the world (Chan, 2011). In fact, family businesses are fast becoming the dominant form of business enterprise in both developing and developed economies. Their influence, as well as their numbers, can be expected to increase substantially in the future as the trend of globalization opens wider business route (Chan, 2011). Small medium enterprises business sector in Malaysia had grew averagely $6.3 \%$ per annum since 2004 (Fialko, 2012). SMEs are more vigilant than the so called giant conglomerates or the government linked companies (GLCs) (Wang, 2012). They are more capable to encounter the negative impacts created during the financial crisis in the late 90s (Ivancevich \& Matteson, 1993). SMEs helped the country to overcome the tremendous both local and global markets changes, contribute to stabilize the economy of the country. Study had shown that countries like Taiwan, Hong Kong, Singapore and Malaysia were on the faster recovery pace during the several past economy crisis because majority of SMEs in these places are owned by Chinese, many of which are operating by family members with highly resilience (Dunne \& Lusch, 2011). Lot of attentions began to focus onto the SMEs by the governments concern due the overwhelming economic 
contributions (Malaysia Budget, 2009). The Malaysian government expects the SMEs continue to sustain its growth at least $8 \%$ for the next few years to meet the Vision 2020 (Azuan, 2012). The focus will be targeted at the service sectors, particularly the trading industry, the retail industry and the related downstream activities. These are components that entail the manufacturing and the construction industries (Jong \& Hartog, 2007). There are great opportunities ahead, the SMEs must be able to re-engineer and re-sharp the business strategies and implement transformation programs in conjunction with the dynamic changes of business condition (Ismail et al., 2009). The government is expecting the SMEs to quantum leap its productivities (Hackman \& Oldham, 2012). According to several authors and consultants, only $30 \%$ of family businesses survive to the second generations, while fewer than $14 \%$ make it beyond the third generation (Fialko, 2012). Smaller family businesses are more vulnerable as they generally survive less than ten years (Wang, 1994). Regarding this matter, Hazel On said, "Owners must first think whether some in the family will want to continue with the business. If not, the other financials and technical aspects would not matter" (Robert, 2001).

Hazel On, the Co-founder of Synergy Planners Colt., an established financial advisory agency with one of the Malaysian leading banks said that before there could be any continuity in business, especially in family businesses, the owner and the partners must plan for the succession road map (Robert, 2001). Generally SMEs do not have a business succession plan although they are aware of it. There is a large gap between awareness and commitment among local SMEs. SMEs that were started in the 80 s and 90 s are starting to face succession issues as their own offspring's are opting to work for some multinational companies in other industries or not return to Malaysia after completed tertiary education (Ismail et al., 2009). At the same time, their long time professional and experienced employees are themselves nearing retirement, while the younger ones are not willing to put in the long years of loyal service typically expected by SMEs before promoted to senior positions at the near retirement ages (Wang, 2012). As globalization is intense, the competition of talent hunting by the MNCs is keen. There might be a need for radical shift in the way SMEs operate in order to continue staying in business even after the founder have retired (Bass, 2011). Being able to entice - calibrate professionals and implement proper working systems are some of the challenges faced. Perhaps a look at how developed countries keep their SMEs going might provide some of the answer the local SMEs are looking for (Birley, 2011). Research in area is scarce Yet, the past research is not conclusive. This study envisages on investigating Malaysian Chinese Family Business Succession in SMEs. There is lack of information available about the Chinese SMEs community that has been involved in the Malaysian business succession program (Azuan, 2012). Relevant empirical information is expected to be gained from the study; such as the economic relationship of the Chinese business and the traditional family own business, the stakeholders expectation, the business environmental factors and most of all the continuation of the Chinese domination in the family business which acts as the pillars of the Malaysian economy (Hall, 2011).

\section{Research Questions}

The research questions for this study are:

1) Does masculinity versus femininity among Chinese family members affect the Family Business Succession?

2) Does individualism versus collectivism among Chinese family members affect the Family Business Succession?

3) Does time orientation among Chinese family members affect the Family Business Succession?

\section{Literature Review}

\subsection{Concern for In-Group}

The traditional business can be viewed as a system and analyzed in terms of its major interrelated variables (sub-systems). The variables can be identified in a number of ways including task, technology, structure, family business and management (Bohlander et al., 2012). All the variables are related to the changes of personality and the ideal of personality of people as lifestyles. In practice, change in any one variable was likely to involve changes in the other variables (Jackson, 2012). The implementation of change can be approached, therefore in terms of a choice of strategies relating to modifications of the task, the technology, the structure, the family business or the management.

\subsection{Distances from In-Group}

In Institutional-based trust such as family business ex-ante deterrents may promote trust, because one's confidence that reputation matters permits relationships to form in the first place. Traditional business institutional factors can act as broad supports for the critical mass of trust that sustains further risk taking and trust behavior. These supports can exist at the family business organizational level in the form of teamwork 
culture and at the societal level, through such cultural supports as legal systems that protect individual rights and property (Yukl, 2012). Both organizational and societal factors affect trust were demonstrated by the examples of comparative research on Hungarian firms under Communist (Chiao, 2011). The absence of within-firm procedures for promoting consistent family members treatment, coupled with the autocratic nature of the Hungarian government, undermined trust and good-faith relations between family leaderships and their family members. In contrast, the United States of America's firms studied enjoyed the benefits of standardized human resources practices within firms (performance reviews and compensation) and legal protections from the federal government. Not surprisingly, trust between supervisors and a subordinate were considerably higher in American firms than in Hungarian ones (Yukl, 2012).

\subsection{Calculus-Based Trust}

Basically, Calculus-based trust was based on rational choice which was related with characteristic of interaction and according to economic exchange. Trust emerges when the "trustees" perceives that the trustee intends to perform an action that was beneficial (Stravou, 1988). The perceived positive intentions in calculus-based trust derive not only from the existence of deterrence but also because of credible information regarding the intentions or competence of another. For instance, credible information about the trusted may be provided by others reputation or any certification such as diploma (Chiao, 2012). Relational trust happened because of information available to the "trustees" from within the relationship itself forms the basis of relational trust. Reliability and dependability in previous interactions with the "trustees" give rise to positive expectations about the trusted one's intentions (Ho, 1976). Repeated interactions can vary considerably in the resources exchanged and in the scope of interdependence between the parties (from repeated family member's employment of contract labor from the same family business to career advancement of full-time family business). Repeated cycles of exchange, risk taking and successful fulfillment of expectations strengthen the willingness of trusting parties (Lansberg, 1988). Thus, an exchange can evolve from an arm's-length transaction into a relationship; from a "fair day's work for a fair day's pay" arrangement to a high-performance employment of family member's relationship characterized by mutual loyalty and broad support (Bass, 2011). Family member's behaviors employees and organizational support from employers of family leadership are characteristic of high levels of relational trust based upon experience within the relationship. In sum, trust was a psychological state composed of the psychological experiences of individuals and firms. Scholars tend to view trust dynamically but focus on specific phases in developing their conceptual framework (Bass, 2011).

\section{Ensuring Adequate Accountability of Family Business}

In order to lay a due foundation for the separate and distinct exercise of the family business cultures, which to a certain extent was admitted to be essential to the preservation of confusions, it was evident that each family members should have a will of its own (Rosener, 1990). Were this principle rigorously adhered to, it would require that all the appointments for the supreme Chinese traditional business should be drawn from the same fountain of clan, the family leadership, through channels with interactions of communication whatever with each other.

\section{The Effects of Uncertainty in Family Business Performance}

It was a great importance in a family business cultures not only to guard their performance against the oppression of economic pressures, but also to guard the politic rules against the injustice of their family business. Different interests necessarily exist in different classes of Chinese small medium enterprises. If a majority be united by a common interest, the rights of these associations will be secure. There are two methods of providing against the family business performance (Ho, 1974):

a) First method prevails in all government possessing a hereditary laws or local government-appointed rules. This, at best, was but a precarious security; because a power independent of the laws and rules may as well espouse the unjust views of traditional Chinese business cultures, as the rightful interests of family business party, and may possibly be turned against both parties.

b) Second method will be exemplified in the protecting certain party rights. Whilst all authority in it will be derived from and dependent on the society, the society itself will be broken into so many parts, interests, and classes of citizens, that the rights of individuals, or of the minority, will be in little danger from interested combinations of the majority. The degree of security in both cases will depend on the number of interests and sects; and this may be presumed to depend on the extent of country and number of people comprehended under the same government especially in the issues of business. 


\section{Method and Material}

\subsection{Interview Process}

The interview is the interaction of researcher with each informant who was involving the give the information from the questionnaire and forms their views, opinions, thoughts and experience. Therefore, it is very important data in the actual study. Interview questions were presented in the structured and open method to allow the informant to provide an explanation and interaction for each of questions given by the researcher. The sample selection also takes into account of differences that exist in every question such as education level, age, years in business, nature of business and knowledge of Chinese family business succession planning. Therefore, the analysis of problems of evaluation Chinese family business succession planning studies is based on structured interview. Then the data is analyzed using the descriptive methods to meet the objectives of the study and to examine Chinese family business succession planning. Only 10 informants were interviewed by the researchers because:

a) The selected respondents have sufficient knowledge and information about the Chinese family business succession planning studies;

b) They are used to work in Chinese family business succession planning; and

c) They were unable to differentiate between Chinese Business and succession planning in Malaysia SME.

\subsection{Data Collection Method}

The interviews began with general questions such as background of the informant, the informant nature of business, level of knowledge and family business succession planning, experience of dealing with business succession planning personally. Through this technique, the informant is willing to provide answers that focused on the objectives of the study. In addition, researchers can follow the interview questions as the interview protocol without any problems. In fact, the focus of questions on two dimensions of the research objectives.

Data collection through interviews and documentation methods of materials related to Chinese family business succession planning has concluded a number of elements that lead to the research objectives. Consequently, this study focuses on the concept of Chinese family business that combines with their succession planning in creating a successful business succession planning. Their family members were also interviewed by the researchers because they can be used as reference and input for future study. A total of 10 informants were interviewed until the end of November 2011. The informants have given their cooperation during the interview which is conducted using structured questions. In addition, the researchers also interviewed many informants via the indirect method by using stratified unstructured interviews. The respondents, mainly Chinese businessmen from three states; Pahang, Terengganu and Kelantan are chosen to the data analysis and foundation. The process of data collection by means of unstructured interviews was conducted from August to October 2011. The predicament faced in collecting the data was that the informants were very busy. Therefore, the unstructured interview method took for three months to complete.

\subsection{The Informants}

Some of the informants do not want their conversation to be recorded by the researchers because they were afraid that their career would be in jeopardy. Therefore, the researchers had to record a number of important information that is related to the objectives of the study. In fact, the informants agreed to put the names but not their real full names. Validity of copying the transcript of this recording has been agreed by the 10 informants interviewed by the researchers. Using of the East coast dialects (Terengganu \& Kelantan) such as Hoekkien and Cantonese is not a problem for researchers. In addition, the interviews were conducted by the researchers in an informal atmosphere. Such conditions are essential to comfort the informants to express their opinions. But sometimes this does not occur and cause researchers to tell that this study be done solely for academic research only. At the beginning of the interview process, the researchers presented a number of questions related to masculinity and femininity in Chinese family business succession planning. This step can provide the basis for a more focused interview to the objectives of the study (Sekaran \& Roger, 2010).

\section{Analysis and Results}

This study involved 10 respondents who serve as informants, as shown in Table 1. The time taken to complete the interviews conducted by researchers will depend on the results that were obtained from the information. The longest time of interviews was conducted is 53 minutes and the shortest time is 31 minutes. The total amount of time allocated to all the interviews conducted was 12 hours and 58 minutes. 
Table 1. The information of each informant involved in interviews

\begin{tabular}{|c|c|c|c|c|}
\hline No & $\begin{array}{l}\text { Informant } \\
\text { Name }\end{array}$ & $\begin{array}{l}\text { Nature of Business and } \\
\text { Years in Business }\end{array}$ & Level of Education & $\begin{array}{l}\text { Total time of interviews } \\
\text { conducted }\end{array}$ \\
\hline 1 & Mr Tan & Manufacturing and 10 years & Secondary School & 45 minutes \\
\hline 2 & Mr Teh & Manufacturing and 23 years & Non-Schooling & 51 minutes \\
\hline 3 & Mr Lim & Wholesaling and 11 years & Secondary School & 48 minutes \\
\hline 4 & $\mathrm{Mr} \mathrm{Ng}$ & Wholesaling and 20 years & Tertiary & 55 minutes \\
\hline 5 & Mr Wong & Retailing and 8 years & Tertiary & 54 minutes \\
\hline 6 & Mr See & Retailing and 24 years & Non Schooling & 49 minutes \\
\hline 7 & Mr Kok & Services and 13 years & Tertiary & 49 minutes \\
\hline 8 & Mr Tang & Services and 21 years & Secondary School & 47 minutes \\
\hline 9 & Mr Tse & Marketing and 7 years & Tertiary & 44 minutes \\
\hline 10 & Mr Khek & Education and 15 years & Tertiary & 50 minutes \\
\hline \multicolumn{4}{|c|}{ Total Time Was Taken For Conducting Interviews } & 492 minutes or 8 hour 12 minutes \\
\hline
\end{tabular}

Source: Based on the research sample in the year of 2011

\subsection{Variable Masculinity and Feminity}

The first question of variable masculinity and femininity was the material success is more important rather than relationships in family business succession. The feedback received regarding the first questions can be classified into three parts, accepting, rejecting and neutrality. The majority of informants indicated that they accept this question at $80 \%$. This is because the acceptance for material success is more important rather than family business succession. Therefore, Mr. See said each Chinese family business will inherit the previous business nature and ideas to their family members especially their sons. But, nowadays these principles are not practices because not all of the family businesses are successful. As an example, if his son can obtain the degree or master and then he will encourage his son to get the better job rather than inherit his business. This happened to Mr. Wong when his son was become a doctor. He, himself encouraged his son not to inherit his retailing business. This proofs that the acceptance of material success can be seen in the success of their son was getting well in the career job. This situation is caused by the difficulties to expand and extend their business. At last, they have no choice but to urge their children to be successful in the education. Through this opinion, mostly the Chinese businessmen will think about their children's future life rather than their business. The largest triumph for them is not to succeed in business but their children's success in life. So, the material success was meant that the main input for Chinese family business was their children are not the business itself. This is supported by Mr. Tse said the real material success is our children because they will shape our lives and needs. The business wills are just a temporary for us to get money. Then, the money will educate and shape our children.

\subsection{Variable Individuality and Collectivism}

In the second questions of valuing achievement in family leadership, $70 \%$ of the respondents accepted. They claimed that the invaluable achievement for them is their children success in their lives. Mr. Teh told the researcher that his will was to see his children to become somebody such as a doctor, engineer or lawyer and so on. This will bring me the happiness and peaceful life if I was passed away. This is recognized and supported by the view Mr. Tang that he will put the welfare of his children first before solving his business matter and finally push the concept of his children to be successful in their lives. Chinese family business will cause the family members to struggle and think out of the box to get a little profit. Whereas, it would be easier to get money by working with others compared involving in business. Sometimes, our children also are not interested in our business. If we force them to inherit it and it will bring a trouble to us. Mr. Lim said that the weakness of the Chinese family business succession was that their children are not ready to inherit their father business. Development of the conceptual distinction between older generations and younger generations obviously the first time when $\mathrm{Mr}$. $\mathrm{Ng}$ himself acknowledges that younger generation will no longer be interested with family business succession planning and this are not priorities for them. Mr. Lim agreed with the statement of magnitude and significance of ethical challenge would help to care for the weak. Hence, almost the younger generations will put forward their ambitions to be somebody rather than continuously their family business. The younger generations was looking down their 
family business because this will make they become weak and the family business are not challenging. So, the older generations have to adopt openness that allows younger generations to voice their opinions and suggestions for their future. Mr. Kok was assuming that the younger generation acts against their family interest to inherit the family business. This can be demonstrated those mostly younger generations to consider the cancellation of family business succession planning. Then, they will not consider inheriting their family business because they were thought that this was a financial burden for them. Sometimes, they were thought that certain areas which are not familiar or too difficult for them to cope with their ability. Reactions from this action will make them always criticized their family business. Hence, the younger generation will consider that their father had betrayed their vision of life.

\subsection{Variable Time Orientation}

Another question for this variable is to achieve my work goals through the assertiveness and modesty. Mr. Khek was saying that younger generation was always designed their vision and mission through their work goals not by business objectives. This could be track through their assertiveness and modesty which they were developed into a career man not a businessman. Instead, he stressed that the younger generations is to become a well-developed career man which they can get it from their education achievement. So, they will prefer to work in private or public sector which was more secured and also they can develop their future career rather than involved in family business. The mentality and spirituality of the younger generations especially Chinese are not looking for family business as their future career. Looking at the problem was the younger generations thought the family business are more challenging than working in the public sector or private sector. They also insists that working in private sector or public sector was received a positive feedback from their friends. In fact, in the family business they have to redouble their efforts to be success and working harder than working in the public or private sector. Analysis of this qualitative study in terms of Chinese family business succession planning concept was found that $90 \%$ of informants agreed that the younger generations are looking down on their family business. This was given them an explanation of the concept of Chinese family business succession planning. Mr. See was disclosed by his a medical lecturer, Mr. Alex See, "If my family inherit their business, the various actions he may be inferred to the three principles of the succession planning in terms of bringing new ideas and methods, developing business capital and family unity. However, due to the limited time factor and the three implementation actions that he did not bear to fruit until now".

Therefore, researcher have done a description of the three actions in the concept Chinese family business succession planning that was being rejected by mostly younger generations are:

1) Bringing new ideas and methods

Chinese family businesses in Malaysia SME have to compete without any aids from the government. Hence, the Chinese Business in SME also has to reform their business method to be globally because the marketing for local business can bring not much profit. Then, the younger generations who will inherit their family business have to change certain policies. The ideas and methods during former leadership of family were continued but renewed with the introduction of new ideas and methods. The architect of their family business can help to retain the old customers and markets. But, this will not hold on in the long time and if economy crisis such as the financial crisis 1997 and 2008. Both crisis have proved that many family business was lost and bankruptcy. Researchers see this as one of the reason why the younger generation will not inherit their family business. In terms of accountability of family business decision-making undertaken by mostly family members, nearly all informants agreed that younger generations play an important role in helping inherit their family business. Therefore, Mr. Khek said the family business is aimed at getting profit to survive the business and educate our children for their future. Implementation of succession planning seen is timely because of the perception of younger generation are not looking their family business as their future career. Mrs. Khek also told the researcher that the younger generations nowadays will opposed if their father wants to inherit his business to his sons or daughters. They will urge their father to leave the business if their father is too old to manage the business. Then, their father have to make a choice either to take drastic leave the business or to take certain effective measures to address to whom should inherit his business. This is because family business has become part of the culture of family members, especially the fathers. So, the father decision is to review the rules of family business succession planning which can result in timely.

\section{2) Developing business capital}

Mr. Tang's view of Chinese business succession planning is to strengthen the family business and not too dependent on his children to inherit his business. In fact, he is also working to improve his children educations for their future. As he was seen that this business will be unable to survive in future because the lost rate is high 
if his passing the baton to his children, who were not interested in it. This high rate lost in family business occurs because his children who are the university graduates from the universities do not meet required quality standards in the family business sector of this country. This cause by the human capital in the form of soft skills was declining especially among university graduates. Mr Tse said to think this situation, he has designed and completed a program of family business succession planning especially developing the business capital. The business capital is not included the material such as money, assets and others. But, business capital also included the human capital such as soft skill, emotional quotation and others. So, the business capital is needed if a father wants to pass the baton of his business to his children. Hence, researchers found that the modern days of Chinese family business succession planning policies implemented by their father has used to address the problem of succession planning only not the family business. But, their children was seen this is not fair to them because the business is their father business not their business. This is supported by the opinion of Mr. Lim said that the purpose of priority succession planning in family business development not only provide more income to our children but also a stability to take over when the time is coming for them. But this purpose can overcome the issue of unfair to our children if they really don't want it anymore. May be we will pass the baton of this family business to whom has been marginalized by our vision.

\section{3) Passage of Time}

Mr. Wong said we were also emphasized the family business sector could provide more profit opportunities, but it has to be renewed in order to grow as the passage of time. One important factor is the competitiveness that should be given priority in the family business because basically it is a magnet for future investment in this age of globalization. Moreover, he stated that efforts to reform not only occur in family business including the succession planning. But also the current interest of our children as they has given priority in contributing family business reforms. Researchers found that the Chinese family business reforms not only occurred in our businesses, but also involving our children. This situation is in conformity with the mission to uplift the status of family business for more distinction, especially as the concept of "Sharing Together for Our Family Future Profit". Mr. Teh agrees that the concept of "Sharing Together for Our Family Future Profit" which led to the existence of family business capital development policies in our business. Business Capital Development Policy is to produce an excellent and first class, especially our family members in delivering their services to our company.

\section{4) Family Unity}

Mr. Tse holds the purpose of family unity ordered as the compulsory for family business succession planning. The emphasis of these family unity elements must be accompanied by our accountability in decision making of direction family business implementation. Overhaul of the direction family business carried out by ours is to improve the performance of family business, including the elimination of lost, competitiveness and increased family business capital. Therefore, it is our tasked to improve the tarnished image of family business with elements of not profitable, less challenges and unproductive. The family business under our direction should be implemented a number of radical changes that speed up the succession planning, eliminating our children interesting and instill the family business thinking among our family members. At last, this will bring the authoritarian rule in our family business and our children will sure against it. The effect of these actions can be seen in incidents of certain Chinese family business have been declared bankruptcy. It is our job to test our children to address their opinion in their future career. If the family business is not their priority career and then we should give them equality time to take over it. As a result, Mr. Wong agrees that the family business succession planning tensions that occurred over the years has resulted in our children to restrict their career direction not on the family business. In this way, we cannot control our children to pursue the family business as their choice of career. Even so, Mr. Tan also shared the same opinion with Mr. Wong said that family business succession planning has become a major problem in family unity. This is due to the existence of luxury pays and status either in the private sector or public sector. As a result, these actions have affected the impact harmonious family unity.

\section{5) Our Children Career}

The difficulties in uniting our children career choices with our ambitions to pass over our business to them. This was seen as a challenge which must be overcome by everybody, as put forward by Mr. See. The researcher also agrees with this truth through the study of the results of the opinion that the older generations were led mostly family business. The older generations claimed that the younger generations was not interested to lead the family business. The younger generations was denying their rights of inheriting their family business and caused the Chinese family business left far behind when compared to old days. They also said the younger generations responsible for many failures of family business. The failure of family business sentiment is not only are making 
their business damaged, but also injured their vital force effort to bring the excellent of family business. Mr. See told that the older generations was showed their pragmatic approach and not based on Machiavelli's approach to force the younger generations to inherit their family business. This shows the maturity of older generations' style in dealing with Chinese family business succession planning nowadays. Results of the interviews showed that all 10 of the informants agreed on Chinese family business succession planning was adopted to obtain the agreement of younger generations and the older generation views of the family business before taking a decision. Even the right of older generations to decide what should be doing is allowed for the family business succession but this opinion is used to improve the succession planning. Here, therefore the older generations always minimize the interference in their children ambitions and dreams to be somebody. It is to ensure smooth transition of succession planning to younger generations was become real. Mr. Lim think, "Even so, the move is considered weak by some but in reality, the move is in the interest of the family. This is because the family businesses that inherit to younger generations are more aware of what is needed and desired by them over the business family succession planning". Researchers agree that by this method, the older generations are able to handle any changes that occur in their family business. Next, their father can control the efficient and effective succession planning without using harsh approach to their children's.

\section{Conclusion and Recommendation}

The key finding of this study is an effort to make the analysis of the Chinese family business succession planning. Therefore, the researcher focuses on the formulation of two research objectives that form the Chinese family business succession planning assessment, the model and the concept of Chinese family business succession planning. Accordingly, this study represents the first attempt to look at business succession planning involving Chinese family business, approach to the Hofstede dimension, the impact of the value dimension and masculinity versus femininity which is the significant variable. In fact, this study connects the three variables in this study. The analysis was conducted on two sources of data through the secondary data and using the qualitative methods. The analysis done on both of these methods to strengthen the study conclusions and make the results more meaningful. The result of this study is to give some important findings namely the qualitative findings indicate that the Chinese family business succession planning is actually influenced by the masculinity and femininity. Hence, this is a positive and significant relationship between one another. In addition, the age factors also play an important role in creating both the family business succession. Among the facts that can prove the existences of these were:

a) The variable masculinity and femininity were found to have a positive and significant relationship with the dependent variable in Chinese family business succession planning of qualitative study. It was actually provides a solution to the researcher. This is because the items selected questions by the respondents in the category of masculinity versus femininity leads to the main ideas in succession planning. In fact, the question items given to the respondents through qualitative interviews conducted also gave a positive answer and they agreed with these ideas may be deemed to exist such as masculinity and femininity. Among the items was a question of believe material success rather than relationship in family business succession, valuing achievement in family leadership, believe magnitude and significance of ethical challenge would help me to care for the weak, achieve my work goals through the assertiveness and modesty and believe in interpersonal harmony in family business succession.

b) The findings also showed some secondary data found in the documentation of the data also show masculinity versus femininity play the major role beside of the qualitative study.

c) The qualitative findings of the study said younger generation prefer not to inherit their family business, the older generations which was running the family business do not object their children wish to work in public or private sector, mostly the younger generations look down on their family business as their career, the younger generations also would like to work outside from their family business because of status and luxury pays, the younger generations also was said that their family business don't have the challenging and future life including the promise of wealth to them. In addition, the younger generations also rejected the practice of family business succession planning that oppresses their means of being allowed to choose their lives. In fact, the researcher are also asking questions like the above to the informant, the informant and her answer was that they agreed that the younger generations is seen with the opinion stated above. However, the problems arise when the period of their father as leader in family business is to be end when they cannot cope with the family business. The effects of the impact of the implementation of their father's stand to inherit their family business will be ended also if there are not have a successor to take over it. (This statement is from Mr. Tse, one of the informants in this study). 


\section{References}

Adler, N. (2012). International dimensions of organizational behaviour. Cincinnati, OH: South Western College Publishing.

Amabile, T. M., Schatzel, E. A., Moneta, G. B., \& Kramer, S. J. (2004). Leader behaviors and the work environment for creativity: Perceived leader support. Leadership Quarterly, 15(1), 5-32. http://dx.doi.org/10.1016/j.leaqua.2003.12.003

Azuan, K. (2012). Pengenalan Pengurusan Perniagaan di Kuala Lumpur. Kuala Lumpur: Utusan Publications.

Bass, B. (2011). Leadership and performance beyond expectations. New York: Free press.

Bass, B. M. (2011). Bass and Stogdill's handbook of leadership: Theory research and managerial applications (3rd ed.). Free Press New York.

Birley, S. (2011). Succession in the family firm: The inheritor's view. Journal of Small Business Management, 24(3), 36-43.

Bohlander et al. (2012). Human Resource Management. New York: Mc Graw Hill.

Burns, J. (2010). Leadership. New York: Harper \& Row.

Chan, K. (2011). Chinese Family Business: A Case Study in Hong Kong. Hong Kong: Macmillan Ltd.

Chiao, C. (2012). Chinese Strategic Behavior: Some General Principles. Claremont:University Press.

Dong, Q., \& Lee, Y. F. (2007). The Chinese Concept of Face: A Perspective for Business Communications. Journal of Business Review, 67, 99-120.

Dunne, P. M., \& Lusch, R. F. (2011). Retailing. New York: South-Western Thomson.

Dyer, W. (1988). Culture and continuity in family firms. Family Business Review, 37-50. http://dx.doi.org/10.1111/j.1741-6248.1988.00037.x

Fialko, J. M. (2012). The Principal of Real Family Business Succession. New York: Prentice Hall.

Grote, J. (2012). Conflicting generations: A new theory of family business rivarly. Family Business Review, 113-124.

Hackman, J. R., \& Oldham, G. R. (2012). Work Redesign. MA: Addison-Wesley.

Hall et al. (2011). Beyond Culture. New York: Double Day.

Ho, D. (1976). On the Concept of Face. American Journal of Society, 81, 867-884. http://dx.doi.org/10.1086/226145

Ismail et al. (2009). Relationship between transformational leadership, empowerment and followers' performance: An empirical study in Malaysia. Revista Científica Electrónica Ciencias Gerenciales, 13(5), $5-22$.

Ivancevich, J. M., \& Matteson, M. T. (1993). Organizational behavior and management. Boston: Richard D. Irwin, Inc.

Jackson, J. C. (2012). Chinese in the West Business: Astede in Cultural Geography. New York: MacMillan.

Jong, P. J. de., \& Hartog, D. N. D. (2007). How leaders influence employees' innovative behaviour. European Journal of Innovation Management, 10, 41-64. http://dx.doi.org/10.1108/14601060710720546

Lansberg, I. (1988). The succession conspiracy. Family Business Review, 119-143. http://dx.doi.org/10.1111/j.1741-6248.1988.00119.x

Robert, D. (2001). Malaysia business in the millennium age. Business Week, 89-94.

Stavrou, E. (1998). A four factor model: A guide to planning next generation involvement in the family firm. Family Business Review, 135-142. http://dx.doi.org/10.1111/j.1741-6248.1998.00135.x

Wang, Y. S. (2012). Individual Modernity and Reactions to frustation. Unpublished Raw Data.

Yukl, G. (2012). Leadership in Organizations. New York: Perason.

\section{Copyrights}

Copyright for this article is retained by the author(s), with first publication rights granted to the journal.

This is an open-access article distributed under the terms and conditions of the Creative Commons Attribution license (http://creativecommons.org/licenses/by/3.0/). 